Supporting Information

\title{
Mild Cleavage of Aryl Mesylates: Methanesulfonate as Convenient Protecting Group for Phenols
}

Tobias Ritter, Kyrill Stanek, Igor Larrosa, and Erick M. Carreira*

Laboratorium für Organische Chemie, ETH-Zürich,

ETH Hönggerberg, HCI, LOC 


\section{Supporting Information}

\section{Materials and Methods}

All reagents and reaction solvents were obtained and purified before use when necessary. Reactions were performed in oven-dried glassware under a slight positive pressure of dry argon. Air- and moisture-sensitive liquids and solutions were transferred under inert atmosphere by syringe. Syringes employed were all polypropylene disposable. Organic solutions were concentrated by rotary evaporation at $40{ }^{\circ} \mathrm{C}$. Diisopropylamine was distilled from $\mathrm{KOH}$. THF and $\mathrm{CH}_{2} \mathrm{Cl}_{2}$ were dried and purified through activated alumina columns as described by Grubbs et al. ${ }^{1}$

Flash chromatography: silica gel $60(230-400$ mesh, $0.04-0.063 \mathrm{~mm})$ from Merck at rt and $0.3-0.5$ mbar air pressure.

Thin layer chromatography (TLC): Merck $0.25 \mathrm{~mm}$ silica gel $60 F_{254}$ TLC glass plates. Visualization of the developed chromatogram was performed by either UV fluorescence at $254 \mathrm{~nm}$ or oxidative stain by ceric ammonium molybdate solution or $\mathrm{KMnO}_{4} / \mathrm{NaHCO}_{3}$ water solution.

Melting points: Büchi 510 apparatus. All melting points were measured in open capillaries and are uncorrected.

IR spectra: Perkin-Elmer Paragon 1000 Fourier Transform single beam spectraphotometer. The samples were prepared as thin films on $\mathrm{NaCl}$ salt plates and are reported as absorption maxima in $\mathrm{cm}^{-1}$.

NMR spectra: ${ }^{1} \mathrm{H},{ }^{13} \mathrm{C}$ NMR spectra were recorded on a Varian Mercury-300 spectrometer operating at $300 \mathrm{MHz}$ for ${ }^{1} \mathrm{H}-\mathrm{NMR}$ and $75 \mathrm{MHz}$ for ${ }^{13} \mathrm{C}-\mathrm{NMR}$. Spectra were referenced internally to residual proton solvent signals. Data for ${ }^{1} \mathrm{H}$ are reported as follows: chemical shift $(\delta, \mathrm{ppm})$, multiplicity $s$ (singlet), $d$ (doublet), $t$ (triplet), $q$ (quartet), and $m$ (multiplet), coupling constant $(\mathrm{J}, \mathrm{Hz})$, integration. Data for ${ }^{13} \mathrm{C}$ are reported in terms of chemical shift $(\delta, \mathrm{ppm})$, coupling constant $(\mathrm{J}, \mathrm{Hz})$ (where appropriate).

Mass spectra: EI mass spectra were performed by the MS service at ETH Zürich.

Elemental analyses: Mikrolabor für Organische Chemie at ETH-Zürich.

Lithium diisopropylamid is prepared by the following procedure: To THF at $-78{ }^{\circ} \mathrm{C}(15.0$ $\mathrm{ml})$ is added diisopropylamine $(1.97 \mathrm{ml}, 1.20$ equiv) followed by $\mathrm{n}-\mathrm{BuLi}(1.61 \mathrm{M}$ in hexane, $7.76 \mathrm{ml}, 1.00$ equiv). The solution is stirred at $-78{ }^{\circ} \mathrm{C}$ for $30 \mathrm{~min}$. 


\section{Supporting Information}

\section{General Procedure for the Preparation of Arylmethanesulfonates.}

To a solution of phenol (1.00 equiv) in $\mathrm{CH}_{2} \mathrm{Cl}_{2}(\mathrm{conc}=1 \mathrm{M})$ at $0{ }^{\circ} \mathrm{C}$ is added $\mathrm{NEt}_{3}(1.50$ equiv). To this solution or suspension is added $\mathrm{MsCl}$ (1.25 equiv) over a period of $15 \mathrm{~min}$. The suspension is stirred at $0{ }^{\circ} \mathrm{C}$ for additional $15 \mathrm{~min}$. To the suspension is added water and the phases are separated. The aqueous phase is extracted with $\mathrm{CH}_{2} \mathrm{Cl}_{2}$. The combined organic phases are washed with brine, dried $\left(\mathrm{Na}_{2} \mathrm{SO}_{4}\right)$ and concentrated in vacuo. The residue is purified by chromatography on silica gel or recrystallized.

\section{General Procedure for the Deprotection of Arylmethanesulfonates.}

To a solution of the methanesulfonate aryl ester (1.00 equiv) in THF (conc= $0.1 \mathrm{M}-1.0 \mathrm{M}$ ) at $-78{ }^{\circ} \mathrm{C}$ to $23{ }^{\circ} \mathrm{C}$ is added a freshly prepared solution of LDA (1.60-1.80 equiv per mesylate group) in THF. After $1-30$ min $5 \%$ aqueous $\mathrm{HCl}$ or aqueous $\mathrm{NH}_{4} \mathrm{Cl}$ is added followed by ethyl acetate. The phases are separated and the aqueous phase is extracted with ethyl acetate or $\mathrm{CH}_{2} \mathrm{Cl}_{2}$. The combined organic phases are washed with brine, dried $\left(\mathrm{Na}_{2} \mathrm{SO}_{4}\right)$ and concentrated in vacuo. The residue is purified by chromatography on silica gel or recrystallized to afford the pure phenols.<smiles>COc1ccc(F)cc1</smiles>

To a solution of 4-fluorophenol (4.00 g, $35.7 \mathrm{mmol}, 1.00$ equiv) in $\mathrm{CH}_{2} \mathrm{Cl}_{2}(35 \mathrm{ml})$ at $0{ }^{\circ} \mathrm{C}$ is added $\mathrm{NEt}_{3}(7.46 \mathrm{ml}, 53.6 \mathrm{mmol}, 1.50$ equiv). To this solution is added $\mathrm{MsCl}(3.45 \mathrm{ml}$, $44.6 \mathrm{mmol}, 1.25$ equiv) over a period of $15 \mathrm{~min}$. The suspension is stirred at $0{ }^{\circ} \mathrm{C}$ for additional $15 \mathrm{~min}$. To the suspension is added water $(10 \mathrm{ml})$. The phases are separated and the aqueous phase is extracted with $\mathrm{CH}_{2} \mathrm{Cl}_{2}(2 * 5 \mathrm{ml})$. The combined organic phases are washed with brine, dried $\left(\mathrm{Na}_{2} \mathrm{SO}_{4}\right)$ and concentrated in vacuo. The residue is purified by chromatography on silica gel eluting with hexane/ ethyl acetate (2/1 to $1 / 1$ gradient) to afford the title compound as a clear liquid in $97 \%$ yield.

$\mathbf{R}_{f}=0.49$ (hexane/ ethyl acetate $1 / 1$ ).

${ }^{1}$ H-NMR (300 MHz, $\left.\mathrm{CDCl}_{3}\right): \delta$ 7.28-7.24 (m, $\left.2 \mathrm{H}\right), 7.13-7.07(m, 2 \mathrm{H}), 3.14(s, 3 \mathrm{H})$.

${ }^{13}$ C-NMR $\left(75 \mathrm{MHz}, \mathrm{CDCl}_{3}\right),: \delta 161.4,(J=247 \mathrm{~Hz}), 145.1,124.0,(J=9 \mathrm{~Hz}), 117.0(J=$ $24 \mathrm{~Hz}), 37.5$.

IR (thin film): 3034, 2942, 1500, 1369, 1195, 1156.

HRMS (EI): Calcd' for $\left(\mathrm{C}_{7} \mathrm{H}_{7} \mathrm{FO}_{3} \mathrm{~S}^{+}\right), 190.0848$; found, 190.0848 .

Anal. Calcd. for $\mathrm{C}_{7} \mathrm{H}_{7} \mathrm{FO}_{3} \mathrm{~S}$ : C, 44.21; H, 3.71; F, 9.99. Found: C, 44.38; H, 4.00. 


\section{Supporting Information}

For

To a solution of methanesulfonic acid 4-fluoro-phenyl ester (382 mg, $2.00 \mathrm{mmol}, 1.00$ equiv) in THF $(4.0 \mathrm{ml})$ at $0{ }^{\circ} \mathrm{C}$ is added a freshly prepared solution of LDA in THF (3.20 mmol, 1.60 equiv). After $1 \mathrm{~min} 5 \%$ aqueous $\mathrm{HCl}$ is added followed by $\mathrm{CH}_{2} \mathrm{Cl}_{2}(20 \mathrm{ml})$. The phases are separated and the aqueous phase is extracted with $\mathrm{CH}_{2} \mathrm{Cl}_{2}$. The combined organic phases are washed with brine, dried $\left(\mathrm{Na}_{2} \mathrm{SO}_{4}\right)$ and concentrated in vacuo. The residue is purified by chromatography on silica gel eluting with hexane/ ethyl acetate $(2 / 1)$ to afford the title compound as a clear liquid in $92 \%$ yield.

${ }^{1}$ H-NMR (300 MHz, $\left.\mathrm{CDCl}_{3}\right): \delta$ 6.96-6.87 ( $\left.m, 2 \mathrm{H}\right), 6.81-6.49(m, 2 \mathrm{H}), 4.58(s, 1 \mathrm{H})$.

This analytical data corresponds to:

Fukuhara, T.; Akiyama, Y.; Yoneda, N.; Tada, T.; Hara, S. Tetrahedron Lett. 2002, 43, 6583-6585.

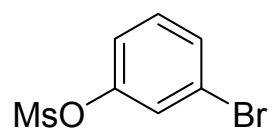

To a solution of 3-bromophenol (4.08 g, $23.6 \mathrm{mmol}, 1.00$ equiv) in $\mathrm{CH}_{2} \mathrm{Cl}_{2}(25 \mathrm{ml})$ at $0{ }^{\circ} \mathrm{C}$ is added $\mathrm{NEt}_{3}(4.83 \mathrm{ml}, 34.7 \mathrm{mmol}, 1.50$ equiv). To this solution is added $\mathrm{MsCl}(2.23 \mathrm{ml}$, $28.9 \mathrm{mmol}, 1.25$ equiv) over a period of $15 \mathrm{~min}$. The suspension is stirred at $0{ }^{\circ} \mathrm{C}$ for additional $15 \mathrm{~min}$. To the suspension is added water $(10 \mathrm{ml})$. The phases are separated and the aqueous phase is extracted with $\mathrm{CH}_{2} \mathrm{Cl}_{2}(2 * 5 \mathrm{ml})$. The combined organic phases are washed with brine, dried $\left(\mathrm{Na}_{2} \mathrm{SO}_{4}\right)$ and concentrated in vacuo. The residue is purified by chromatography on silica gel eluting with hexane/ ethyl acetate (2/1 to $1 / 1$ gradient) to afford the title compound as a clear liquid in $97 \%$ yield.

$\mathbf{R}_{f}=0.50$ (hexane/ ethyl acetate 1/1).

${ }^{1}$ H-NMR $\left(300 \mathrm{MHz}, \mathrm{CDCl}_{3}\right): \delta$ 7.49-7.45 (m, $\left.2 \mathrm{H}\right), 7.33-7.22(m, 2 \mathrm{H}), 3.16(s, 3 \mathrm{H})$.

${ }^{13}$ C-NMR $\left(75 \mathrm{MHz} \mathrm{CDCl}_{3}\right)$ ): $\delta$ 149.6, 131.3, 130.9, 125.7, 123.1, 121.1, 38.9.

IR (thin film): 3094, 3032, 2940, 1581, 1468, 1371, 1197, 1156, 890.

HRMS (EI): Calcd' for $\left(\mathrm{C}_{7} \mathrm{H}_{7} \mathrm{BrO}_{3} \mathrm{~S}^{+}\right)$, 249.9299; found, 249.9276.

Anal. Calcd. for $\mathrm{C}_{7} \mathrm{H}_{7} \mathrm{BrO}_{3} \mathrm{~S}$ : C, 33.48; H, 2.81; found: C, 33.53; H, 2.87. 


\section{Supporting Information}

Br

To a solution of methanesulfonic acid 3-bromo-phenyl ester (502 mg, $2.00 \mathrm{mmol}, 1.00$ equiv) in THF $(2.0 \mathrm{ml})$ at $0{ }^{\circ} \mathrm{C}$ is added a freshly prepared solution of LDA in THF (3.00 mmol, 1.50 equiv). After $5 \mathrm{~min} 5 \%$ aqueous $\mathrm{HCl}(10 \mathrm{ml})$ is added followed by ethyl acetate $(20 \mathrm{ml})$. The phases are separated and the aqueous phase is extracted with ethyl acetate. The combined organic phases are washed with brine, dried $\left(\mathrm{Na}_{2} \mathrm{SO}_{4}\right)$ and concentrated in vacuo. The residue is purified by chromatography on silica gel eluting with hexane/ ethyl acetate $(2 / 1)$ to afford the title compound in $95 \%$ yield.

${ }^{1}$ H-NMR (300 MHz, $\left.\mathrm{CDCl}_{3}\right): \delta$ 7.14-7.01 (m, $\left.3 \mathrm{H}\right), 6.79-6.74(m, 1 \mathrm{H}), 4.99(s, 1 \mathrm{H})$.

Fischer, A.; Henderson, G.; Narayanan, C. Can. J. Chem. 1983, 63, 1045-1052

Proof of purity: Anal. Calcd. for $\mathrm{C}_{6} \mathrm{H}_{5} \mathrm{BrO}$ : C, 41.65; H, 2.91; found: C, 41.93; H, 3.13 .

For further analytical data, see: Brossi, A.; Hsu, F.-L.; Rice, K. C.; Rozwadowska, M. D.; Schmidhammer, H. Helv. Chim. Acta 1981, 64, 1672-1681.<smiles>COc1ccccc1I</smiles>

To a solution of 2-iodophenol $\left(2.00 \mathrm{~g}, 9.10 \mathrm{mmol}, 1.00\right.$ equiv) in $\mathrm{CH}_{2} \mathrm{Cl}_{2}(10 \mathrm{ml})$ at $0{ }^{\circ} \mathrm{C}$ is added $\mathrm{NEt}_{3}$ (1.90 ml, $13.6 \mathrm{mmol}, 1.50$ equiv). To this solution is added $\mathrm{MsCl}(0.920 \mathrm{ml}$, $11.4 \mathrm{mmol}, 1.25$ equiv) over a period of $20 \mathrm{~min}$. The suspension is stirred at $0{ }^{\circ} \mathrm{C}$ for additional $15 \mathrm{~min}$. To the suspension is added water $(10 \mathrm{ml})$. The phases are separated and the aqueous phase is extracted with $\mathrm{CH}_{2} \mathrm{Cl}_{2}$. The combined organic phases are washed with brine, dried $\left(\mathrm{Na}_{2} \mathrm{SO}_{4}\right)$ and concentrated in vacuo. The residue is purified by chromatography on silica gel eluting with hexane/ ethyl acetate $(2 / 1)$ to afford the title compound in $94 \%$ yield.

$\mathbf{R}_{f}=0.42$ (hexane/ ethyl acetate 2/1).

${ }^{1}$ H-NMR $\left(300 \mathrm{MHz}, \mathrm{CDCl}_{3}\right): \delta 7.84(d d, J=7.8 \mathrm{~Hz}, 1.6 \mathrm{~Hz}, 1 \mathrm{H})$, 7.47-7.35 (m,

$2 \mathrm{H}), 7.03(m, 1 \mathrm{~Hz}), 3.28(s, 3 \mathrm{H})$.

${ }^{13}$ C-NMR (75 MHz, $\left.\mathrm{CDCl}_{3}\right)$,: $\delta$ 149.7, 140.4, 130.2, 129.0, 123.4, 89.9, 39.5.

IR (thin film): 3030, 2937, 1573, 1463, 1440, 1371, 1204, 1169, 969, 861.

HRMS (EI): Calcd' for $\left(\mathrm{C}_{7} \mathrm{H}_{7} \mathrm{IO}_{3} \mathrm{~S}^{+}\right)$, 297.9161; found, 297.9156.

Anal. Calcd. for $\mathrm{C}_{7} \mathrm{H}_{7} \mathrm{IO}_{3} \mathrm{~S}$ : C, 28.20; H, 2.37; found: C, 28.32; H, 2.41. 


\section{Supporting Information}<smiles>Oc1ccccc1I</smiles>

To a solution of methanesulfonic acid 2-iodo-phenyl ester (596 mg, $2.00 \mathrm{mmol}, 1.00$ equiv) in THF $(2.0 \mathrm{ml})$ at $0{ }^{\circ} \mathrm{C}$ is added a freshly prepared solution of LDA in THF (3.20 mmol, 1.60 equiv). After $1 \mathrm{~min} 5 \%$ aqueous $\mathrm{HCl}(10 \mathrm{ml})$ is added followed by ethyl acetate $(20 \mathrm{ml})$. The phases are separated and the aqueous phase is extracted with ethyl acetate. The combined organic phases are washed with brine, dried $\left(\mathrm{Na}_{2} \mathrm{SO}_{4}\right)$ and concentrated in vacuo. The residue is purified by chromatography on silica gel eluting with hexane/ ethyl acetate $(2 / 1)$ to afford the title compound in $93 \%$ yield.

${ }^{1}$ H-NMR $\left(300 \mathrm{MHz}, \mathrm{CDCl}_{3}\right): \delta 7.66(d d, J=7.9 \mathrm{~Hz}, 1.5 \mathrm{~Hz}, 1 \mathrm{H}), 7.24(m, 1 \mathrm{H}), 6.99$ (dd, $J=8.2 \mathrm{~Hz}, 1.5 \mathrm{~Hz}, 1 \mathrm{H}), 6.68(m, 1 \mathrm{H}), 5.29(s, 1 \mathrm{H})$.

This analytical data corresponds to: Kitagawa, H.; Shibata, T.; Matsuo, J.; Mukaiyama, T. Bull. Chem. Soc. Jpn. 2002, 75, 339 - 346.

Proof of purity: Anal. Calcd. for $\mathrm{C}_{6} \mathrm{H}_{5} \mathrm{IO}$ : C, 32.76; H, 2.29; found: C, 33.06; H, 2.35.<smiles>COc1cccc(OC)c1OC</smiles>

To a solution of 2,6-dimethoxyphenol (1.54 g, $10.0 \mathrm{mmol}, 1.00$ equiv) in $\mathrm{CH}_{2} \mathrm{Cl}_{2}(20 \mathrm{ml})$ at $0{ }^{\circ} \mathrm{C}$ is added $\mathrm{NEt}_{3}(2.09 \mathrm{ml}, 15.0 \mathrm{mmol}, 1.50$ equiv $)$. To this solution is added $\mathrm{MsCl}(0.970$ $\mathrm{ml}, 12.5 \mathrm{mmol}, 1.25$ equiv) over a period of $5 \mathrm{~min}$. The suspension is stirred at $0{ }^{\circ} \mathrm{C}$ for additional $15 \mathrm{~min}$. To the suspension is added aqueous $\mathrm{NH}_{4} \mathrm{Cl}(8 \mathrm{ml})$. The phases are separated and the aqueous phase is extracted with $\mathrm{CH}_{2} \mathrm{Cl}_{2}$. The combined organic phases are washed with $2 \mathrm{~N} \mathrm{HCl}(20 \mathrm{ml})$, water $(20 \mathrm{ml})$, and brine $(20 \mathrm{ml})$, dried $\left(\mathrm{Na}_{2} \mathrm{SO}_{4}\right)$ and concentrated in vacuo to afford the title compound in $100 \%$ yield.

mp: $98^{\circ} \mathrm{C}$.

$\mathbf{R}_{\boldsymbol{f}}=0.42$ (hexane/ ethyl acetate $2 / 1$ ).

${ }^{1}$ H-NMR $\left(300 \mathrm{MHz}, \mathrm{CDCl}_{3}\right): \delta 7.16(t, J=8.4 \mathrm{~Hz}, 1 \mathrm{H}), 6.61(d, J=8.4 \mathrm{~Hz}, 2 \mathrm{H}), 3.88$ $(s, 6 \mathrm{~Hz}), 3.29(s, 3 \mathrm{H})$.

${ }^{13}$ C-NMR (75 MHz, $\left.\mathrm{CDCl}_{3}\right)$,: $\delta$ 153.1, 128.1, 127.3, 104.9, 56.3, 39.9.

IR (thin film): 3037, 2977, 1608, 1508, 1493, 1448, 1365, 1307, 1111, 870, 779.

Anal. Calcd. for $\mathrm{C}_{9} \mathrm{H}_{12} \mathrm{O}_{5} \mathrm{~S}$ : C, 46.54; H, 5.21; found: C, 46.60; H, 5.38. 


\section{Supporting Information}<smiles>COc1cccc(OC)c1O</smiles>

To a solution of methanesulfonic acid 2,6-dimethoxy-phenyl ester (112 mg, $0.500 \mathrm{mmol}$, 1.00 equiv) in THF $(5.0 \mathrm{ml})$ at $0{ }^{\circ} \mathrm{C}$ is added a freshly prepared solution of LDA in THF ( $0.901 \mathrm{mmol}, 1.80$ equiv). After $1 \mathrm{~min} 5 \%$ aqueous $\mathrm{HCl}(10 \mathrm{ml})$ is added followed by ethyl acetate $(20 \mathrm{ml})$. The phases are separated and the aqueous phase is extracted with ethyl acetate. The combined organic phases are washed with brine, dried $\left(\mathrm{Na}_{2} \mathrm{SO}_{4}\right)$ and concentrated in vacuo. The residue is purified by chromatography on silica gel eluting with $\mathrm{CH}_{2} \mathrm{Cl}_{2}$ to afford the title compound in $95 \%$ yield.

${ }^{1}$ H-NMR $\left(300 \mathrm{MHz} \mathrm{CDCl}_{3}\right): \delta 6.87(t, J=8.1 \mathrm{~Hz}, 1 \mathrm{H}), 6.57(d, J=8.1 \mathrm{~Hz}, 1 \mathrm{H}), 5.55(s$, $1 \mathrm{H}), 3.86(s, 6 \mathrm{H})$.

This analytical data corresponds to:

Jing, X.; Gu, W.; Bie, P.; Ren, X.; Pan, X. Synth. Commun, 2001, 31, 861-868.<smiles>COc1cccc(N(C)C)c1</smiles>

To a solution of 3-dimethylaminophenol (2.00 g, $14.6 \mathrm{mmol}, 1.00$ equiv) in $\mathrm{CH}_{2} \mathrm{Cl}_{2}$ (15 ml) at $0{ }^{\circ} \mathrm{C}$ is added $\mathrm{NEt}_{3}(6.10 \mathrm{ml}, 21.9 \mathrm{mmol}, 1.50$ equiv). To this solution is added $\mathrm{MsCl}$ ( $1.47 \mathrm{ml}, 18.2 \mathrm{mmol}, 1.25$ equiv) over a period of $20 \mathrm{~min}$. The suspension is stirred at $0{ }^{\circ} \mathrm{C}$ for additional $15 \mathrm{~min}$. To the suspension is added water $(10 \mathrm{ml})$. The phases are separated and the aqueous phase is extracted with $\mathrm{CH}_{2} \mathrm{Cl}_{2}$. The combined organic phases are washed with brine, dried $\left(\mathrm{Na}_{2} \mathrm{SO}_{4}\right)$ and concentrated in vacuo. The residue is purified by chromatography on silica gel eluting with hexane/ ethyl acetate $(2 / 1)$ to afford the title compound in $92 \%$ yield.

mp: $50{ }^{\circ} \mathrm{C}$

$\mathbf{R}_{f}=0.27$ (hexane/ ethyl acetate 2/1).

${ }^{1}$ H-NMR $\left(300 \mathrm{MHz}, \mathrm{CDCl}_{3}\right): \delta$ 7.24-718 (m, $\left.1 \mathrm{H}\right), 6.65-6.57(m, 3 \mathrm{H}), 3.11(\mathrm{~s}, 3 \mathrm{H}), 2.96$ $(s, 6 \mathrm{H})$.

${ }^{13}$ C-NMR (75 MHz, $\left.\mathrm{CDCl}_{3}\right)$ ): $\delta$ 152.1, 150.9, 130.3, 111.2, 108.9, 105.7, 40.6, 37.4.

IR (thin film): 2938, 2812, 1611, 1570, 1506, 1363, 1179, 1130.

MS (ESI): Calcd' for $\left(\mathrm{C}_{7} \mathrm{H}_{7} \mathrm{IO}_{3} \mathrm{SH}^{+}\right), 216.1$; found, 216.2 .

Anal. Calcd. for $\mathrm{C}_{9} \mathrm{H}_{13} \mathrm{O}_{3} \mathrm{~S}$ : C, 50.21; H, 6.09; N, 6.51; found: C, 50.36; H, 6.15; N, 6.53. 


\section{Supporting Information}<smiles>CNc1cccc(O)c1</smiles>

To a solution of methanesulfonic acid 3-dimethylamino-phenyl ester (432 mg, 2.00 mmol, 1.00 equiv) in THF $(2.0 \mathrm{ml})$ at $0{ }^{\circ} \mathrm{C}$ is added a freshly prepared solution of LDA in THF (3.20 mmol, 1.60 equiv). After $1 \mathrm{~min} \mathrm{NH}_{4} \mathrm{Cl}(0.5 \mathrm{~g})$ is added and the suspension is concentrated. To the residue is added $\mathrm{CH}_{2} \mathrm{Cl}_{2}$ and water. The phases are separated and the aqueous phase is extracted with $\mathrm{CH}_{2} \mathrm{Cl}_{2}$. The combined organic phases are washed with brine, dried $\left(\mathrm{Na}_{2} \mathrm{SO}_{4}\right)$ and concentrated in vacuo. The residue is purified by chromatography on silica gel eluting with hexane/ ethyl acetate (2/1) to afford the title compound in $89 \%$ yield.

${ }^{1}$ H-NMR $\left(300 \mathrm{MHz}, \mathrm{CDCl}_{3}\right): \delta$ 7.13-7.07 ( $\left.m, 1 \mathrm{H}\right), 6.37-6.32(m, 1 \mathrm{H}), 6.24-6.18(m, 2 \mathrm{H})$, $4.94(s, 1 \mathrm{H}), 2.92(s, 6 \mathrm{H})$.

This analytical data corresponds to: Jacquesy, J.-C.; Jouannetaud, M.-P.; Morellet, G.; Vidal, Y. Bull. Soc. Chim. Fr. 1986, 625-629.

Proof of purity: Anal. Calcd. for $\mathrm{C}_{8} \mathrm{H}_{11} \mathrm{NO}$ : C, 70.04; H, 8.08; found: C, 69.81; H, 8.22.<smiles>COc1cc(F)ccc1[N+](=O)[O-]</smiles>

To a solution of 5-fluoro-2-nitrophenol (1.57 g, $10.0 \mathrm{mmol}, 1.00$ equiv) in acetone (20 ml) at $23{ }^{\circ} \mathrm{C}$ is added $\mathrm{K}_{2} \mathrm{CO}_{3}(1.66 \mathrm{~g}, 12.0 \mathrm{mmol}, 1.20$ equiv). To this suspension is added $\mathrm{MsCl}$ ( $1.48 \mathrm{~g}, 11.0 \mathrm{mmol}, 1.10$ equiv). The suspension is stirred at $23{ }^{\circ} \mathrm{C}$ until all starting material was consumed as assayed by TLC. The suspension in concentrated and ethyl acetate (40 $\mathrm{ml})$ and brine $(10 \mathrm{ml})$ are added. The phases are separated and the organic phase is concentrated in vacuo. The residue is purified by chromatography on silica gel eluting with hexane/ $\mathrm{CH}_{2} \mathrm{Cl}_{2}$ (2/3) to afford the title compound in $96 \%$ yield.

${ }^{1}$ H-NMR $\left(300 \mathrm{MHz}, \mathrm{CDCl}_{3}\right): \delta 8.14(d d, J=9.3 \mathrm{~Hz}, 5.6 \mathrm{~Hz}, 1 \mathrm{H}), 7.31(d d, J=8.4 \mathrm{~Hz}$, $2.8 \mathrm{~Hz}, 1 \mathrm{H}), 7.18(d d d, J=9.3 \mathrm{~Hz}, 6.84 \mathrm{~Hz}, 2.5 \mathrm{~Hz}, 1 \mathrm{H}), 3.39(s, 3 \mathrm{H})$.

${ }^{13}$ C-NMR $\left(75 \mathrm{MHz}, \mathrm{CDCl}_{3}\right),: \delta 164.6(d, J=258 \mathrm{~Hz}), 114.9(d, J=22 \mathrm{~Hz}), 113.3(d, J=$ $22 \mathrm{~Hz}), 39.4$.

IR (thin film): 3584, 3117, 2943, 1560, 1534, 1486, 1354, 1274, 1186, 1146, 1082, 997 , 808,614 .

MS (EI): Calcd' for $\left(\mathrm{C}_{7} \mathrm{H}_{6} \mathrm{FNO}_{5} \mathrm{~S}^{+}\right)$, 235.1; found, 235.0 .

Anal. Calcd. for $\mathrm{C}_{7} \mathrm{H}_{6} \mathrm{FNO}_{5} \mathrm{~S}$ : C, 35.75; H, 2.57, N, 5.96; found: C, 35.70; H, 2.75; N, 6.17. 


\section{Supporting Information}<smiles>O=[N+]([O-])c1ccc(F)cc1O</smiles>

To a solution of methanesulfonic acid 5-fluoro-2-nitro-phenyl ester (112 mg, 0.500 mmol, 1.00 equiv) in THF $(5.0 \mathrm{ml})$ at $-78^{\circ} \mathrm{C}$ is added a freshly prepared solution of LDA in THF ( $0.900 \mathrm{mmol}, 1.80$ equiv). After $1 \mathrm{~min}$ aqueous $\mathrm{NH}_{4} \mathrm{Cl}(4 \mathrm{ml})$ is added followed by $\mathrm{CH}_{2} \mathrm{Cl}_{2}$. The phases are separated and the aqueous phase is extracted with $\mathrm{CH}_{2} \mathrm{Cl}_{2}$. The combined organic phases are washed with brine, dried $\left(\mathrm{Na}_{2} \mathrm{SO}_{4}\right)$ and concentrated in vacuo. The residue is purified by chromatography on silica gel eluting with $\mathrm{CH}_{2} \mathrm{Cl}_{2}$ to afford the title compound in $67 \%$ yield.

mp: $33^{\circ} \mathrm{C}-35^{\circ} \mathrm{C}$

This analytical data corresponds to:

Nicholson, H. J. Chem. Soc. 1939, 1405-1408.

For further analytical data, see: Gerson, H.; Clarke, D. D.; Gershon, M. Monatsh. Chem. 1995, 126, 1161-1166.<smiles>COc1ccc([N+](=O)[O-])cc1OC</smiles>

To a solution of 2-methoxy-4-nitrophenol (3.00 g, $17.7 \mathrm{mmol}, 1.00$ equiv) in $\mathrm{CH}_{2} \mathrm{Cl}_{2}(20$ $\mathrm{ml})$ at $0{ }^{\circ} \mathrm{C}$ is added $\mathrm{NEt}_{3}(3.70 \mathrm{ml}, 26.6 \mathrm{mmol}, 1.50$ equiv). To this solution is added $\mathrm{MsCl}$ ( $1.79 \mathrm{ml}, 22.2 \mathrm{mmol}, 1.25$ equiv) over a period of $30 \mathrm{~min}$. The suspension is stirred at $0{ }^{\circ} \mathrm{C}$ for additional $15 \mathrm{~min}$. To the suspension is added water $(10 \mathrm{ml})$. The phases are separated and the aqueous phase is extracted with $\mathrm{CH}_{2} \mathrm{Cl}_{2}$. The combined organic phases are washed with brine, dried $\left(\mathrm{Na}_{2} \mathrm{SO}_{4}\right)$ and concentrated in vacuo. The residue is recrystallized from ethyl acetate to afford the title compound in $97 \%$ yield.

mp: $108^{\circ} \mathrm{C}$

$\mathbf{R}_{\boldsymbol{f}}=0.36$ (hexane/ ethyl acetate $3 / 2$ ).

${ }^{1}$ H-NMR $\left(300 \mathrm{MHz}, \mathrm{CDCl}_{3}\right): \delta$ 7.89-7.85 (m, $\left.2 \mathrm{H}\right)$, 7.46-7.42 (m, $\left.1 \mathrm{H}\right), 4.00(s, 3 \mathrm{H}), 3.26$ $(s, 3 \mathrm{H})$.

${ }^{13}$ C-NMR (75 MHz, $\left.\mathrm{CDCl}_{3}\right)$ ): $\delta$ 152.2, 147.2, 143.0, 125.0, 116.8, 108.4, 56.9, 39.2.

IR (thin film): 3093, 3045, 2944, 1534, 1497, 1360, 1348, 1326, 1268, 1162, 1020.

HRMS (EI): Calcd' for $\left(\mathrm{C}_{8} \mathrm{H}_{9} \mathrm{NO}_{6} \mathrm{~S}^{+}\right), 247.0151$; found, 247.0150 .

Anal. Calcd. for $\mathrm{C}_{8} \mathrm{H}_{9} \mathrm{NO}_{6} \mathrm{~S}: \mathrm{C}, 38.87 ; \mathrm{H}, 3.67, \mathrm{~N}, 5.67$; found: $\mathrm{C}, 38.83 ; \mathrm{H}, 3.76 ; \mathrm{N}, 5.58$. 


\section{Supporting Information}

$\overbrace{\mathrm{OMe}}^{\mathrm{NO}_{2}}$

To a solution of methanesulfonic acid 2-methoxy-4-nitro-phenyl ester (494 mg, 2.00 mmol, 1.00 equiv) in THF $(4.0 \mathrm{ml})$ at $23{ }^{\circ} \mathrm{C}$ is added a freshly prepared solution of LDA in THF (3.20 mmol, 1.60 equiv). After $30 \mathrm{~min} 5 \%$ aqueous $\mathrm{HCl}(10 \mathrm{ml})$ is added followed by ethyl acetate. The phases are separated and the aqueous phase is extracted with ethyl acetate. The combined organic phases are washed with brine, dried $\left(\mathrm{Na}_{2} \mathrm{SO}_{4}\right)$ and concentrated in vacuo. The residue is purified by chromatography on silica gel eluting with hexane/ ethyl acetate $(2 / 1)$ to afford the title compound in $65 \%$ yield.

${ }^{1}$ H-NMR $\left(300 \mathrm{MHz}, \mathrm{CDCl}_{3}\right): \delta 7.89(d d, J=8.7 \mathrm{H}, 2.5 \mathrm{~Hz}, 1 \mathrm{H}), 7.77(d, J=2.6 \mathrm{~Hz}, 1 \mathrm{H})$, $6.98(d, J=8.7 \mathrm{~Hz}, 1 \mathrm{H}), 6.22(s, 1 \mathrm{H}), 4.00(s, 3 \mathrm{H})$.

Proof of purity: Anal. Calcd. for $\mathrm{C}_{7} \mathrm{H}_{7} \mathrm{NO}_{4}$ : C, 49.71; H, 4.17, N, 8.28; found: C, 49.84; $\mathrm{H}$, $4.29 ; \mathrm{N}, 8.16$.

This analytical data corresponds to:

Harvison, P.; Forte, A. J.; Nelson, S; Sidney, D. J. Med. Chem. 1986, 29, 1737-1743.<smiles>COc1cc([13C](C)(C)C)c(OC)cc1C(C)(C)C</smiles>

To a solution of 2-5-di-tert-butylhydroquinone (4.00 g, $18.0 \mathrm{mmol}, 1.00$ equiv) in $\mathrm{CH}_{2} \mathrm{Cl}_{2}$ $(20 \mathrm{ml})$ at $0{ }^{\circ} \mathrm{C}$ is added $\mathrm{NEt}_{3}(7.52 \mathrm{ml}, 54.0 \mathrm{mmol}, 3.00$ equiv). To this solution is added $\mathrm{MsCl}(3.63 \mathrm{ml}, 45.0 \mathrm{mmol}, 2.50$ equiv) over a period of $15 \mathrm{~min}$. The suspension is stirred at $0{ }^{\circ} \mathrm{C}$ for additional $15 \mathrm{~min}$. To the suspension is added water $(10 \mathrm{ml})$. The phases are separated and the aqueous phase is extracted with $\mathrm{CH}_{2} \mathrm{Cl}_{2}$. The combined organic phases are washed with brine, dried $\left(\mathrm{Na}_{2} \mathrm{SO}_{4}\right)$ and concentrated in vacuo. The residue is recrystallized from ethyl acetate to afford the title compound in $77 \%$ yield.

mp: $173^{\circ} \mathrm{C}$

$\mathbf{R}_{\boldsymbol{f}}=0.15$ (hexane/ ethyl acetate 5/1).

${ }^{1}$ H-NMR (300 MHz, $\left.\mathrm{CDCl}_{3}\right): \delta 7.58(s, 2 \mathrm{H}), 3.25(s, 6 \mathrm{H}), 1.39(s, 18 \mathrm{H})$.

${ }^{13}$ C-NMR (75 MHz, $\left.\mathrm{CDCl}_{3}\right)$,: $\delta$ 146.2, 140.5, 120.9, 39.4, 34.8, 30.4.

IR (thin film): 3019, 2942,2873, 1501, 1347, 1193, 1157, 1110, 871.

HRMS (EI): Calcd' for $\left(\mathrm{C}_{16} \mathrm{H}_{26} \mathrm{O}_{6} \mathrm{~S}_{2}{ }^{+}\right)$, 378.1171; found, 378.1171 .

Anal. Calcd. for $\mathrm{C}_{16} \mathrm{H}_{26} \mathrm{O}_{6} \mathrm{~S}_{2}$ : C, 75.63; H, 9.97; found: C, 75.36; H, 9.91. 


\section{Supporting Information}<smiles>Oc1cc(Br)c(Br)cc1O</smiles>

To a solution of methanesulfonic acid 2,5-di-tert-butyl-4-methanesulfonyloxy-phenyl ester $\left(757 \mathrm{mg}, 2.00 \mathrm{mmol}, 1.00\right.$ equiv) in THF $(15.0 \mathrm{ml})$ at $0{ }^{\circ} \mathrm{C}$ is added a freshly prepared solution of LDA in THF (6.40 mmol, 3.20 equiv). After $30 \mathrm{~min} 5 \%$ aqueous $\mathrm{HCl}(9 \mathrm{ml})$ is added followed by ethyl acetate. The phases are separated and the aqueous phase is extracted with ethyl acetate. The combined organic phases are washed with brine, dried $\left(\mathrm{Na}_{2} \mathrm{SO}_{4}\right)$ and concentrated in vacuo. The residue is purified by chromatography on silica gel eluting with hexane/ ethyl acetate $(5 / 1)$ to afford the title compound in $70 \%$ yield.

mp: $216^{\circ} \mathrm{C}$.

This analytical data corresponds to:

Fujita, S.; Sano, K. J. Org. Chem. 1979, 44, 2647-2651.

Proof of purity: Anal. Calcd. for $\mathrm{C}_{14} \mathrm{H}_{22} \mathrm{O}_{2}$ : C, 75.63; H, 9.97; found: C, 75.36; H, 9.91.

For further analytical data, see: Shulgin, A. T.; Kerlinger, H. O. Tetrahedron Lett., 1965, 6, 3355-3359.

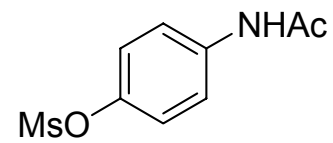

To a solution of 4-acetamidophenol (4.00 g, $26.5 \mathrm{mmol}, 1.00$ equiv) in $\mathrm{CH}_{2} \mathrm{Cl}_{2}(50 \mathrm{ml})$ at 0 ${ }^{\circ} \mathrm{C}$ is added $\mathrm{NEt}_{3}(5.53 \mathrm{ml}, 39.7 \mathrm{mmol}, 1.50$ equiv). To this solution is added $\mathrm{MsCl}(2.67$ $\mathrm{ml}, 33.0 \mathrm{mmol}, 1.25$ equiv) over a period of $30 \mathrm{~min}$. The suspension is stirred at $0{ }^{\circ} \mathrm{C}$ for additional $15 \mathrm{~min}$. To the suspension is added water $(25 \mathrm{ml})$ and ethyl acetate $(600 \mathrm{ml})$. The phases are separated and the aqueous phase is extracted with ethyl acetate. The combined organic phases are washed with brine, dried $\left(\mathrm{Na}_{2} \mathrm{SO}_{4}\right)$ and concentrated in vacuo. The residue is recrystallized from ethyl acetate to afford the title compound in $78 \%$ yield.

mp: $177^{\circ} \mathrm{C}$

$\mathbf{R}_{\boldsymbol{f}}=0.41\left(\mathrm{MeOH} / \mathrm{CH}_{2} \mathrm{Cl}_{2} 8 / 92\right)$.

${ }^{1}$ H-NMR $\left(300 \mathrm{MHz}\right.$, acetone $\left.\mathrm{d}_{6}\right): \delta 9.31(s, 1 \mathrm{H}), 7.72(m, 2 \mathrm{H}), 7.25(m, 2 \mathrm{H}), 3.24(s, 3$ $\mathrm{H}), 2.08(s, 3 \mathrm{H})$.

${ }^{13}$ C-NMR (75 MHz, acetone $\left.\mathrm{d}_{6}\right)$,: $\delta$ 168.7, 145.4, 139.2, 123.1, 120.7, 37.2, 24.1.

IR (thin film): 3300, 1664, 1538, 1365, 1194, 1156, 834.

MS (EI): Calcd' for $\left(\mathrm{C}_{9} \mathrm{H}_{11} \mathrm{NO}_{4} \mathrm{~S}^{+}\right), 229.0$; found, 229.0.

Anal. Calcd. for $\mathrm{C}_{9} \mathrm{H}_{11} \mathrm{NO}_{4} \mathrm{~S}$ : C, 47.15; H, 4.84, N, 6.11; found: C, 47.33; H, 4.94, N, 6.19. 


\section{Supporting Information}

NHAc

To a solution of methanesulfonic acid 4-acetamido-phenyl ester (459 mg, $2.00 \mathrm{mmol}$, 1.00 equiv) in THF $(20 \mathrm{ml})$ at $23^{\circ} \mathrm{C}$ is added a freshly prepared solution of LDA in THF ( $12.0 \mathrm{mmol}, 6.0$ equiv). After $30 \mathrm{~min} 5 \%$ aqueous $\mathrm{HCl}(10 \mathrm{ml})$ is added followed by ethyl acetate. The phases are separated and the aqueous phase is extracted with ethyl acetate. The combined organic phases are washed with brine, dried $\left(\mathrm{Na}_{2} \mathrm{SO}_{4}\right)$ and concentrated in vacuo. The residue is purified by chromatography on silica gel eluting with $\mathrm{CH}_{2} \mathrm{Cl}_{2} / \mathrm{MeOH}$ (95/5 to $90 / 10$ gradient) to afford the title compound in $66 \%$ yield.

mp: $168^{\circ} \mathrm{C}-172{ }^{\circ} \mathrm{C}$

This data corresponds to: Ritter, F. O. J. Am. Chem. Soc. 1934, 56, 975-976.<smiles>COc1cccnc1Br</smiles>

To a solution of 2-bromo-3-hydroxypyridine ( $1.74 \mathrm{~g}, 10.0 \mathrm{mmol}, 1.00$ equiv) in acetone (20 $\mathrm{ml})$ at $0{ }^{\circ} \mathrm{C}$ is added $\mathrm{K}_{2} \mathrm{CO}_{3}(1.66 \mathrm{~g}, 12.0 \mathrm{mmol}, 1.20$ equiv). To this suspension is added $\mathrm{MsCl}$ (1.48 g, $11.0 \mathrm{mmol}, 1.10$ equiv). The suspension is stirred at $23{ }^{\circ} \mathrm{C}$ for $1 \mathrm{~h}$. The suspension in concentrated and ethyl acetate $(40 \mathrm{ml})$ and brine $(10 \mathrm{ml})$ are added. The aqueous phase is extracted with ethyl acetate. The combined organic phases are washed with brine and concentrated in vacuo. The residue is purified by chromatography on silica gel eluting with hexane/ $\mathrm{CH}_{2} \mathrm{Cl}_{2}$ (4/1) to afford the title compound in $94 \%$ yield.

${ }^{1}$ H-NMR $\left(300 \mathrm{MHz}, \mathrm{CDCl}_{3}\right): \delta 8.34(d d, J=4.7 \mathrm{~Hz}, 1.6 \mathrm{~Hz}, 1 \mathrm{H}), 7.76(d d, J=8.1 \mathrm{~Hz}$, $1.9 \mathrm{~Hz}, 1 \mathrm{H}), 7.36(d d, J=8.1 \mathrm{~Hz}, 4.7 \mathrm{~Hz}, 1 \mathrm{H}), 3.33(s, 3 \mathrm{H})$.

${ }^{13}$ C-NMR (75 MHz, $\left.\mathrm{CDCl}_{3}\right)$ ): $\delta$ 148.0, 143.9, 135.7, 132.1, 127.8, 39.5.

IR (thin film): 3132, 3032, 2937, 1568, 1409, 1372, 1175, 1062, 860.

MS (EI): Calcd' for $\left(\mathrm{C}_{9} \mathrm{H}_{11} \mathrm{NO}_{4} \mathrm{~S}^{+}\right), 250.9252$; found, 250.9251.<smiles>Oc1cccnc1Br</smiles>

To a solution of methanesulfonic acid 2-bromo-pyridin-3-yl ester $(252 \mathrm{mg}, 1.00 \mathrm{mmol}$, 1.00 equiv) in THF $(10 \mathrm{ml})$ at $23{ }^{\circ} \mathrm{C}$ is added a freshly prepared solution of LDA in THF ( $1.80 \mathrm{mmol}, 1.80$ equiv). After $30 \mathrm{~min} 5 \%$ aqueous $\mathrm{NH}_{4} \mathrm{Cl}(4 \mathrm{ml})$ is added followed by ethyl acetate. The phases are separated and the aqueous phase is extracted with ethyl acetate. The combined organic phases are washed with brine, dried $\left(\mathrm{Na}_{2} \mathrm{SO}_{4}\right)$ and 


\section{Supporting Information}

concentrated in vacuo. The residue is purified by chromatography on silica gel eluting with $\mathrm{CH}_{2} \mathrm{Cl}_{2} /$ ethyl acetate (3/2) to afford the title compound in $57 \%$ yield.

mp: $184{ }^{\circ} \mathrm{C}$

This data corresponds to: Hasseberg, H.-A.; Gerlach, H. Helv. Chim. Acta 1988, 71, 957963.<smiles>COc1ccnc2ccccc12</smiles>

To a solution of 4-hydroxyquinoline $\left(0.500 \mathrm{~g}, 3.44 \mathrm{mmol}, 1.00\right.$ equiv) in $\mathrm{CH}_{2} \mathrm{Cl}_{2}(5.0 \mathrm{ml})$ at $0{ }^{\circ} \mathrm{C}$ is added $\mathrm{NEt}_{3}(0.720 \mathrm{ml}, 5.17 \mathrm{mmol}, 1.50$ equiv). To this solution is added $\mathrm{MsCl}$ $(0.350 \mathrm{ml}, 4.31 \mathrm{mmol}, 1.25$ equiv) over a period of $30 \mathrm{~min}$. The suspension is stirred at 0 ${ }^{\circ} \mathrm{C}$ for additional $15 \mathrm{~min}$. To the suspension is added water $(25 \mathrm{ml})$ and $\mathrm{CH}_{2} \mathrm{Cl}_{2}$. The phases are separated and the aqueous phase is extracted with $\mathrm{CH}_{2} \mathrm{Cl}_{2}$. The combined organic phases are washed with brine, dried $\left(\mathrm{Na}_{2} \mathrm{SO}_{4}\right)$ and concentrated in vacuo. The residue is purified by chromatography on silica gel eluting with toluene/ ethyl acetate (3/1 to $1 / 1$ gradient) to afford the title compounds in $52 \%$ and $36 \%$, respectively.<smiles>COc1ccnc2ccccc12</smiles>

mp: $70{ }^{\circ} \mathrm{C}$

$\mathbf{R}_{f}=0.24$ (toluene/ ethyl acetate $3 / 2$ ).

${ }^{1}$ H-NMR (300 MHz, CDCl $): \delta 8.87(d, J=5.0 \mathrm{~Hz}, 1 \mathrm{H}), 8.08(m, 2 \mathrm{H}), 7.73(m, 1 \mathrm{H})$, $7.58(m, 2 \mathrm{H}), .7 .43(d, J=5.0 \mathrm{~Hz}, 1 \mathrm{H}), 3.26(s, 3 \mathrm{H})$.

${ }^{13}$ C-NMR $\left(75 \mathrm{MHz}, \mathrm{CDCl}_{3}\right)$ ): $\delta 152.7,151.0,150.4,130.8,129.8,127.9,122.2,121.5$, $112.2,38.8$.

IR (thin film): 3032, 2936, 1599, 1502, 1372, 1181, 1154, 1085, 893.

HRMS (EI): Calcd' for $\left(\mathrm{C}_{10} \mathrm{H}_{9} \mathrm{NO}_{3} \mathrm{~S}^{+}\right), 223.0303$; found, 223.0312 .

Anal. Calcd. for $\mathrm{C}_{10} \mathrm{H}_{9} \mathrm{NO}_{3} \mathrm{~S}$ : C, 53.80; H, 4.06, N, 6.27; found: C, 53.95; H, 4.13, N, 6.27. 


\section{Supporting Information}<smiles>CS(=O)(=O)n1ccc(=O)c2ccccc21</smiles>

mp: $145^{\circ} \mathrm{C}$

$\mathbf{R}_{f}=0.17$ (toluene/ ethyl acetate $3 / 2$ ).

${ }^{1}$ H-NMR $\left(300 \mathrm{MHz}, \mathrm{CDCl}_{3}\right): \delta 8.42(d d, J=7.8 \mathrm{~Hz}, 1.6 \mathrm{~Hz}, 1 \mathrm{H}), 8.27(d, J=8.7 \mathrm{~Hz}, 1$ $\mathrm{H}), 8.24(m, 1 \mathrm{H}), 7.64(m, 1 \mathrm{H}), 7.50(m, 1 \mathrm{H}), 6.53(d, J=8.7 \mathrm{~Hz}, 1 \mathrm{H}), 3.37(s, 3 \mathrm{H})$.

${ }^{13}$ C-NMR $\left(75 \mathrm{MHz}, \mathrm{CDCl}_{3}\right),: \delta$ 178.0, 137.2, 137.0, 133.3, 127.6, 126.4, 125.9, 117.5, 112.4, 41.2.

IR (thin film): 3009, 2926, 1640, 1640, 1609, 1468, 1362, 1173, 1104.

HRMS (EI): Calcd' for $\left(\mathrm{C}_{10} \mathrm{H}_{9} \mathrm{NO}_{3} \mathrm{~S}^{+}\right), 223.2$; found, 223.2 .

Anal. Calcd. for $\mathrm{C}_{10} \mathrm{H}_{9} \mathrm{NO}_{3} \mathrm{~S}$ : C, 53.80; H, 4.06, N, 6.27; found: C, 53.88; H, 4.08, N, 6.27.<smiles>Oc1ccnc2ccccc12</smiles>

To a solution of methanesulfonic acid quinolin-4-yl ester $(112 \mathrm{mg}, 0.490 \mathrm{mmol}, 1.00$ equiv) in THF $(1.0 \mathrm{ml})$ at $0{ }^{\circ} \mathrm{C}$ is added a freshly prepared solution of LDA in THF $(0.800$ mmol, 1.60 equiv). After $5 \mathrm{~min} 5 \%$ aqueous $\mathrm{HCl}(5 \mathrm{ml})$ is added followed by $\mathrm{CH}_{2} \mathrm{Cl}_{2}$. The phases are separated and the aqueous phase is extracted with $\mathrm{CH}_{2} \mathrm{Cl}_{2}$. The combined organic phases are washed with brine, dried $\left(\mathrm{Na}_{2} \mathrm{SO}_{4}\right)$ and concentrated in vacuo. The residue is purified by trituration in acetone to afford the title compound in $68 \%$ yield.

mp: $202{ }^{\circ} \mathrm{C}-206^{\circ} \mathrm{C}$

Proof of purity: Anal. Calcd. for $\mathrm{C}_{9} \mathrm{H}_{7} \mathrm{NO}$ : C, 74.47; H, 4.86; N, 9.65; found: $\mathrm{C}, 74.38$; $\mathrm{H}$, $5.07 ; \mathrm{N}, 9.86$.

This analytical data corresponds to:

Katagiri, N.; Niwa, R.; Furuya, Y.; Kato, T. Chem. Pharm. Bull. 1983, 6, 1833-1841. 


\section{Supporting Information}<smiles>Oc1ccnc2ccccc12</smiles>

To a solution of 1-methanesulfonyl-4a,8a-dihydro-1H-quinolin-4-one (110 mg, 0.500 mmol, 1.00 equiv) in THF $(4.0 \mathrm{ml})$ at $0{ }^{\circ} \mathrm{C}$ is added a freshly prepared solution of LDA in THF ( $0.800 \mathrm{mmol}, 1.60$ equiv). After $5 \mathrm{~min} 5 \%$ aqueous $\mathrm{HCl}(5 \mathrm{ml})$ is added followed by ethyl acetate. The phases are separated and the aqueous phase is extracted with ethyl acetate. The combined organic phases are washed with brine, dried $\left(\mathrm{Na}_{2} \mathrm{SO}_{4}\right)$ and concentrated in vacuo. The residue is purified by trituration in acetone to afford the title compound in $72 \%$ yield.

mp: $202{ }^{\circ} \mathrm{C}-206^{\circ} \mathrm{C}$<smiles>C=CCc1c(C(C=C)C2OC(c3ccccc3)O[C@@]2(CO)C[C@H](C)O)ccc(O)c1OCC</smiles>

To a solution of the $1(1.40 \mathrm{~g}, 2.63 \mathrm{mmol}, 1.00$ equiv $)$ in THF $(53.0 \mathrm{ml})$ at $-78{ }^{\circ} \mathrm{C}$ is added a freshly prepared solution of LDA in THF (10.5 mmol, 4.00 equiv). The suspension is warmed to $0^{\circ} \mathrm{C}$. After $5 \min 0.5 \mathrm{ml} \mathrm{MeOH}$ are added, followed by aqueous $\mathrm{NH}_{4} \mathrm{Cl}$ and ethyl acetate. The phases are separated and the aqueous phase is extracted with ethyl acetate. The combined organic phases are washed with brine, dried $\left(\mathrm{Na}_{2} \mathrm{SO}_{4}\right)$ and concentrated in vacuo. The residue is purified by chromatography on silica gel eluting with hexane/ ethyl acetate (1/2 to $1 / 3$ gradient) to afford the title compound in $82 \%$ yield.

$\mathbf{R}_{f}=0.31$ (hexane/ ethyl acetate $1 / 2$ )

$\alpha_{\mathrm{D}}=54^{\circ},\left(\mathrm{CHCl}_{3}, \mathrm{c}=0.280,22.8^{\circ} \mathrm{C}\right.$.

mp: $134{ }^{\circ} \mathrm{C}$.

${ }^{1}$ H-NMR (300 MHz, MeOD): $\delta 7.42(m, 5 \mathrm{H}), 6.95(d, J=8.7 \mathrm{~Hz}), 6.76(d, J=8.7 \mathrm{~Hz})$, $6.15(m, 1 \mathrm{H}), 5.99-5.84(m, 2 \mathrm{H}), 5.14-4.64(m, 6 \mathrm{H}), 3.98(m, 3 \mathrm{H}), 3.78(m, 2 \mathrm{H}), 3.50(m$, $2 \mathrm{H}), 3.243 .78(m, 3 \mathrm{H}), 1.72(m, 1 \mathrm{~Hz}), 1.36(t, J=7.1 \mathrm{~Hz}, 3 \mathrm{H}), 1.22(m, 1 \mathrm{H}), 1.39(d, J$ $=7.1 \mathrm{~Hz}, 3 \mathrm{H})$.

${ }^{13}$ C-NMR $(75 \mathrm{MHz}, \mathrm{MeOD}),: \delta 149.1,145.6,140.5,138.6,137.3,132.2,129.6,129.0$, $128.1,126.7,123.9,114.9,114.4,102.5,84.2,82.7,68.4,64.9,63.4,44.0,42.7,30.8,24.2$, 14.7.

IR (thin film): 3307, 3083, 2978, 1637, 1597, 1488, 1440, 1406, 1295, 1104, 1065, 1050.

HRMS (Maldi): Calcd' for $\left(\mathrm{C}_{27} \mathrm{H}_{34} \mathrm{O}_{6} \mathrm{Na}^{+}\right)$, 477.2253; found, 477.2243.

Anal. Calcd. for $\mathrm{C}_{27} \mathrm{H}_{34} \mathrm{O}_{6}$ : C, 71.34; H, 7.54; found: C, 71.17; H, 7.61. 


\section{Supporting Information}<smiles>C=CCc1c(C(C=C)(C=C)C2OC(c3ccccc3)OC2(COC)OCC)ccc(O)c1OCC</smiles>

To a solution of $2(200 \mathrm{mg}, 0.288 \mathrm{mmol}, 1.00$ equiv $)$ in $\mathrm{THF}(3.0 \mathrm{ml})$ at $-78{ }^{\circ} \mathrm{C}$ is added a freshly prepared solution of LDA in THF ( $0.461 \mathrm{mmol}, 1.60$ equiv). After 2 min aqueous $\mathrm{NH}_{4} \mathrm{Cl}$ is added followed by ethyl acetate. The phases are separated and the aqueous phase is extracted with ethyl acetate. The combined organic phases are washed with brine, dried $\left(\mathrm{Na}_{2} \mathrm{SO}_{4}\right)$ and concentrated in vacuo. The residue is purified by chromatography on silica gel eluting with hexane/ ethyl acetate (3/2) to afford the title compound in $79 \%$ yield.

$\mathbf{R}_{\boldsymbol{f}}=0.31$ (hexane/ ethyl acetate $3 / 2$ ).

$\alpha_{\mathrm{D}}=54^{\circ},\left(\mathrm{CHCl}_{3}, \mathrm{c}=0.395,28.3^{\circ} \mathrm{C}\right.$.

${ }^{1}$ H-NMR $\left(300 \mathrm{MHz}, \mathrm{CDCl}_{3}\right): \delta 7.42(m, 5 \mathrm{H}), 6.95(d, J=8.7 \mathrm{~Hz}), 6.82(d, J=8.7 \mathrm{~Hz})$, $6.18(m, 1 \mathrm{H}), 5.99-5.84(m, 2 \mathrm{H}), 5.14-4.84(m, 6 \mathrm{H}), 4.72(d, J=9.3 \mathrm{~Hz}) 4.63(d, J=9.3$ $\mathrm{Hz}), 3.93(q, J=7.1 \mathrm{~Hz}, 2 \mathrm{H}), 3.74(m, 1 \mathrm{H}), 3.59-3.38(m, 2 \mathrm{H}), 3.00(s, 3 \mathrm{H}), 1.44(t, J=$ $7.1 \mathrm{~Hz}, 3 \mathrm{H}), 1.39(d, J=7.1 \mathrm{~Hz}, 3 \mathrm{H}), 1.29(s, 9 \mathrm{H})$.

${ }^{13}$ C-NMR (75 MHz, $\left.\mathrm{CDCl}_{3}\right)$ ): $\delta$ 177.8, 148.6, 145.4, 139.5, 137.5, 136.6, 131.6, 129.7, $128.7,126.6,124.4,116.8,116.6,114.0,103.1,82.4,81.5,70.4,64.9,43.5,40.5,39.1$, $39.0,31.0,27.6,23.4,16.0$.

IR (thin film): 3448, 2977, 2935, 1731, 1637, 1481, 1353, 1291, 1174, 913, 897.

HRMS (Maldi): Calcd' for $\left(\mathrm{C}_{33} \mathrm{H}_{44} \mathrm{O}_{9} \mathrm{SNa}^{+}\right), 639.2604$; found, 639.2590.<smiles>C=CCc1c(C(C=C)[C@H](O)[C@]2(CO)C[C@H](C)OC(C)(C)O2)ccc(OC)c1OCC</smiles>

To a solution of the aldehyde $6\left(24.2 \mathrm{~g}, 80.0 \mathrm{mmol}, 1.00\right.$ equiv) in DMF $(32 \mathrm{ml})$ at $0{ }^{\circ} \mathrm{C}$ is added Rieke zinc. ${ }^{2}$ To this suspension is added a solution of bromide 5 ( $37.5 \mathrm{~g}, 100$ mmole, 1.25 equiv) in DMF $(10 \mathrm{ml})$ at $0{ }^{\circ} \mathrm{C}$ over a period of $3.5 \mathrm{~h}$. After addition the slurry is warmed to $23{ }^{\circ} \mathrm{C}$ and stirred for additional $30 \mathrm{~min}$. The suspension is diluted with ethyl acetate $(100 \mathrm{~m})$ and poured onto aqueous $\mathrm{NH}_{4} \mathrm{Cl}$ solution. The phases are separated and the aqueous phase is extracted with ethyl acetate $(3 * 40 \mathrm{ml})$. The combined organic phases are washed with brine, dried $\left(\mathrm{Na}_{2} \mathrm{SO}_{4}\right)$ and concentrated in vacuo. The residue is purified by 


\section{Supporting Information}

chromatography on silica gel eluting with hexane/ ethyl acetate (3/1) collecting fractions at $\mathrm{R}_{f}=0.55$ (hexane/ ethyl acetate $\left.3 / 1\right)$. This material is dissolved in THF $(120 \mathrm{ml})$ at $0{ }^{\circ} \mathrm{C}$ and TBAF in THF (1.00 M, $76.2 \mathrm{ml}, 1.25$ equiv) is added. The solution is stirred at $0{ }^{\circ} \mathrm{C}$ for $30 \mathrm{~min}$. The solution is diluted with ethyl acetate $(250 \mathrm{ml})$ and aqueous $\mathrm{NaHCO}_{3}$ solution $(250 \mathrm{ml})$. The phases are separated and the aqueous phase is extracted with ethyl acetate (3* $40 \mathrm{ml})$. The combined organic phases are washed with brine, dried $\left(\mathrm{Na}_{2} \mathrm{SO}_{4}\right)$ and concentrated in vacuo. The residue is purified by chromatography on silica gel eluting with hexane/ ethyl acetate (3/2) to afford the title compound in $41 \%$ yield along with a diastereomer $(23 \%)$.

$\mathbf{R}_{f}=0.41$ (hexane/ ethyl acetate 1/1).

$\alpha_{D}=-5.5^{\circ},\left(\mathrm{CHCl}_{3}, \mathrm{c}=0.325,25.2^{\circ} \mathrm{C}\right.$.

${ }^{1}$ H-NMR $\left(300 \mathrm{MHz}, \mathrm{CDCl}_{3}\right): \delta 7.33(d, J=9.7 \mathrm{~Hz}, 1 \mathrm{H}), 7.20(d, J=9.3 \mathrm{~Hz}, 1 \mathrm{H}), 6.37-$ $6.25(m, 1 \mathrm{H}), 6.02-5.93(m, 1 \mathrm{H}), 5.16-4.85(m, 4 \mathrm{H}), 4.02-3.85(m, 5 \mathrm{H}), 3.64-3.43(m, 4$ $\mathrm{H}), 3.11(s, 3 \mathrm{H}), 2.67(s, 1 \mathrm{H}), 2.45(s, 1 \mathrm{H}), 2.08(d d, J=15.3 \mathrm{~Hz}, 5.7 \mathrm{~Hz}, 1 \mathrm{H}), 1.42-1.15$ $(m, 13 \mathrm{H})$.

${ }^{13}$ C-NMR (75 MHz, $\left.\mathrm{CDCl}_{3}\right)$ ): $\delta$ 149.0, 143.4, 141.1, 137.0, 136.6, 132.2, 124.6, 122.1, $118.1,115.5,99.9,78.2,77.9,70.4,67.6,62.7,44.6,37.8,34.5,30.4,30.0,26.2,22.5,15.8$.

IR (thin film): 3535, 2979, 2936, 1476, 1369, 1173, 967.

HRMS (Maldi): Calcd' for $\left(\mathrm{C}_{24} \mathrm{H}_{36} \mathrm{O}_{6} \mathrm{SNa}^{+}\right)$, 507.2029; found, 507.2018.

\footnotetext{
${ }^{1}$ A. B. Pangborn, M. A. Giardello, R. H. Grubbs, R. K. Rosen, F. J. Timmers, Organometallics 1996, 15, 1518.

${ }^{2}$ R. D. Rieke, P. T. J. Li, T. P. Burns, S. T. Uhm J. Org. Chem. 1981, 46, 4323-4324.
} 